\title{
Effects of Selected Anionic $\beta$-Cyclodextrins on Persistence of Blood Glucose Lowering by Insulin Glargine after Subcutaneous Injection to Rats
}

\author{
Keiko Uehata, ${ }^{1}$ Takayuki Anno, ${ }^{1}$ Kayoko Hayashida, ${ }^{1}$ \\ Keiichi Motoyama, ${ }^{1}$ Taishi Higashi, ${ }^{1}$ Fumitoshi Hirayama, ${ }^{2}$ Naomi Ono, ${ }^{3}$ \\ James D. Pipkin, ${ }^{3}$ Kaneto Uekama, ${ }^{2}$ and Hidetoshi Arima ${ }^{1}$ \\ ${ }^{1}$ Graduate School of Pharmaceutical Sciences, Kumamoto University, 5-1 Oe-honmachi, Kumamoto 862-0973, Japan \\ ${ }^{2}$ Faculty of Pharmaceutical Sciences, Sojo University, 4-22-1 Ikeda, Kumamoto 860-0082, Japan \\ ${ }^{3}$ CyDex Pharmaceuticals, Inc., Lenexa, KS 66214-1643, USA \\ Correspondence should be addressed to Hidetoshi Arima, arimah@gpo.kumamoto-u.ac.jp
}

Received 29 July 2011; Accepted 19 September 2011

Academic Editor: Roberta Cavalli

Copyright (C) 2011 Keiko Uehata et al. This is an open access article distributed under the Creative Commons Attribution License, which permits unrestricted use, distribution, and reproduction in any medium, provided the original work is properly cited.

Insulin glargine is a synthetic long-acting insulin product used for patients with diabetes mellitus. In this study, to obtain the further desirable blood-glucose lowering profile of insulin glargine, we investigated the effects of $\beta$-cyclodextrin sulfate (Sul- $\beta$ $\mathrm{CyD}$ ) and sulfobutylether $\beta$-cyclodextrin (SBE7- $\beta$-CyD) on physicochemical properties of insulin glargine and pharmacokinetics/ pharmacodynamics of insulin glargine after subcutaneous injection to rats. Sul- $\beta$-CyD and SBE7- $\beta$-CyD increased solubility of insulin glargine. SBE7- $\beta$-CyD suppressed the formation of oligomer and enhanced the dissolution rate of insulin glargine from its precipitate, compared to that of Sul- $\beta$-CyD. Additionally, we revealed that after subcutaneous administration of an insulin glargine solution, SBE7- $\beta$-CyD, but not Sul- $\beta$-CyD, increased bioavailability and sustained the blood-glucose lowering effect, possibly due to the inhibitory effects of SBE7- $\beta$-CyD on the enzymatic degradation at the injection site. These results suggest that SBE7- $\beta$-CyD could be a useful excipient for sustained release of insulin glargine.

\section{Introduction}

Diabetes is a rapidly growing health problem worldwide and chronic disease wherein the pancreas does not produce enough insulin (type 1 diabetes), or the body does not respond correctly to insulin and relative insulin deficiency (type 2 diabetes). It can be a life-threatening disease and can also lead to serious complications such as cardiovascular disease, kidney failure, blindness, and nerve damage [1-3]. According to the World Health Organization, the number of people living with diabetes is estimated to increase from 172 million in 2000 to 366 million in 2030 [4]. The global diabetes epidemic has devastating effects on not only patients and their families but also national economies.

Human insulin is a major backbone for the treatment of diabetes. Although human insulin has contributed much in clinical treatment of diabetes for a long time, there are still some difficulties and challenges of hypoglycemia and short half-life. In order to overcome these drawbacks, insulin glargine (Lantus), an insulin analogue $\left(\mathrm{C}_{267} \mathrm{H}_{404} \mathrm{~N}_{72} \mathrm{O}_{78} \mathrm{~S}_{6}\right.$, $\mathrm{MW}=6,063)$ was developed by replacing asparagine at the position of 21 of the A chain with glycine, and two arginines were added to the C-terminus of the $\mathrm{B}$ chain in human insulin (Figure 1). It has a prolonged duration of action after subcutaneous injection and, therefore, can provide a basal insulin level for 24 hours by once daily injection [5]. This alteration results in low aqueous solubility at neutral $\mathrm{pH}$ [6]. Insulin glargine is supplied in an acidic solution, which becomes neutralized at the injection site, leading to the formation of microprecipitates from which insulin glargine is slowly released into the circulation [6].

Cyclodextrins (CyDs) are known to form inclusion complexes with various guest molecules $[7,8]$. However, the low aqueous solubility of natural CyDs, especially $\beta$-CyD, 


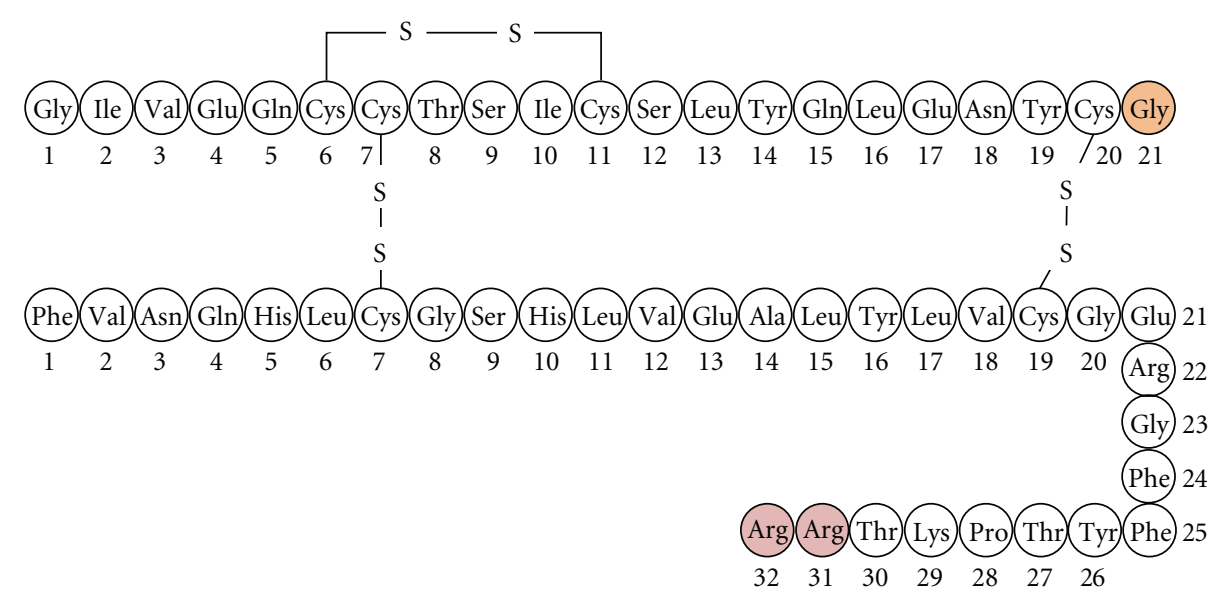

FIGURE 1: Amino acid sequence and location of intermolecular disulfide bonds of insulin glargine.

has restricted their range of applications. To improve their solubility, alkylated, hydroxyl alkylated, sulfated, sulfobutyl alkylated, and branched CyDs have been developed [9-12] . Of these hydrophilic CyDs, maltosyl- $\beta$-CyD $\left(\mathrm{G}_{2}-\beta-\mathrm{CyD}\right), 2-$ hydroxypropyl- $\beta$-CyD (HP- $\beta$-CyD), $\beta$-CyD sulfate (Sul- $\beta$ $\mathrm{CyD})$ and sulfobutyl ether- $\beta$-CyD (SBE- $\beta$-CyD) have higher solubility in water and relatively low hemolytic activity and thus have potential as pharmaceutical excipients for parenteral preparation $[8,9,13]$. In fact, natural $\beta$-CyD has a toxic effect on kidney, which is the main organ for the removal of CyDs from the systemic circulation and for concentrating CyDs in the proximal convoluted tubule after glomerular filtration [14]. Actually, amorphous mixtures of highly water-soluble $\beta$-CyDs such as HP- $\beta$-CyD and SBE- $\beta$ CyD have very low systemic toxicity, compared with $\beta$-CyD.

We previously reported the effects of hydrophilic $\beta$-CyDs on the aggregation of bovine insulin in aqueous solution and its adsorption onto hydrophilic surfaces [15-17]. Of the CyDs tested, $\mathrm{G}_{2}-\beta-\mathrm{CyD}$ potently inhibited insulin aggregation in a neutral solution and its adsorption onto the surfaces of glass and polypropylene tubes. In addition, SBE- $\beta$-CyDs showed different effects on insulin aggregation in phosphate buffer $(\mathrm{pH} 6.8, I=0.2)$, depending on the degree of substitution (DS) of the sulfobutyl ether group, SBE4- $\beta$-CyD $(\mathrm{DS}=3.9)$ showed deceleration of insulin aggregation, and SBE7- $\beta$-CyD (DS = 6.2) showed acceleration [17]. Furthermore, we reported that after subcutaneous administration of insulin solution to rats, SBE4- $\beta$-CyD rapidly increased plasma insulin level and maintained higher plasma insulin levels for at least $8 \mathrm{~h}$, possibly due to the inhibitory effects of SBE4- $\beta$-CyD on the enzymatic degradation and/or the adsorption of insulin onto the subcutaneous tissue at the injection site [18]. More recently, we have demonstrated that SBE4- $\beta$-CyD enhanced both bioavailability and prolonged the blood-glucose lowering effect of insulin glargine after subcutaneous administration to rats, probably due to the inhibitory effects of interaction with SBE4- $\beta$-CyD on the enzymatic degradation at the injection site [19]. However, it is still unknown whether other anionic $\beta$-CyD derivatives such as Sul- $\beta-$ CyD and SBE7- $\beta-$ CyD show the improved bioavailability and sustained-glucose lowering effects for insulin glargine. Therefore, the objective in the present study is to evaluate the potential use of anionic $\beta-C y D$ derivatives, such as Sul- $\beta-$ CyD and SBE7- $\beta-C y D$, on not only bioavailability of insulin glargine but also the sustainedblood-glucose lowering effects. In addition, the effects of Sul$\beta-C y D$ and SBE7- $\beta$-CyD on physicochemical properties and pharmacokinetics/pharmacodynamics of insulin glargine were examined.

\section{Materials and Methods}

2.1. Materials. Insulin glargine was supplied by SanofiAventis (Paris, France). SBE7- $\beta$-CyD was provided by CyDex (Kansas, USA). Sul- $\beta$-CyD with an average degree of substitution of 10.7 was prepared by a nonregional selective method as described previously [20]. Recombinant trypsin (EC 3.4.21.4) of proteomics grade was purchased from Roche Diagnostics (Tokyo, Japan). Phosphate buffer ( $\mathrm{pH}$ 9.5, $I=0.2$ ) was prepared according to the US Pharmacopeia; $0.1 \mathrm{~mol} / \mathrm{L}$ phosphoric acid solution and $0.1 \mathrm{~mol} / \mathrm{L}$ sodium hydroxide solution were mixed, followed by the addition of sodium chloride. All other materials were of analytical reagent grade, and deionized double-distilled water was used.

2.2. Spectroscopic Studies. Fluorescence and circular dichroism (CD) spectra were measured at $25^{\circ} \mathrm{C}$ using a HITACHI fluorescence spectrophotometer F-2500 (Tokyo, Japan) and a JASCO J-720 polarimeter (Tokyo, Japan), respectively.

2.3. Solubility Studies. Excess amounts of insulin glargine were shaken in phosphate buffer $(\mathrm{pH} 9.5, I=0.2)$ in the absence and presence of the selected anionic $\beta$-CyDs at $25^{\circ} \mathrm{C}$. After equilibrium was attained, the solutions were filtered with Millex GV filter $0.22 \mu \mathrm{m}$, and the insulin glargine dissolved was determined by high-performance liquid chromatography (HPLC) with Agilent 1100 series (Tokyo, Japan) under the following conditions: Merck Superspher 100 RP18 column ( $4 \mu \mathrm{m}, 3 \mathrm{~mm} \times 250 \mathrm{~mm}$, Tokyo, Japan), a mobile phase of phosphate buffer ( $\mathrm{pH} 2.5)$ and acetonitrile and a 
gradient flow, increasing the ratio of the acetonitrile (25$40 \%$ ) over $30 \mathrm{~min}$, a flow rate of $0.55 \mathrm{~mL} / \mathrm{min}$, a detection of UV at $214 \mathrm{~nm}$.

2.4. Ultrafiltration Studies. Ultrafiltration studies were performed using stirred ultrafiltration cells model 8010 (Millipore, Tokyo, Japan) applied with YM30 ultrafiltration discs $(\mathrm{MWCO}=30,000)$ in phosphate buffer $(\mathrm{pH} 9.5, I=0.2)$ in the absence and presence of the selected anionic $\beta$-CyDs at $25^{\circ} \mathrm{C}$ under nitrogen current. Insulin glargine levels in filtrates were determined by HPLC as described above.

2.5. Particle Size Determination. Particle sizes of insulin glargine $(0.1 \mathrm{mM})$ with or without the selected anionic $\beta$-CyDs $(10 \mathrm{mM})$ in phosphate buffer $(\mathrm{pH} 9.5, I=0.2)$ were measured by Zetasizer Nano (Malvern Instruments, Worcestershire, UK).

2.6. Dissolution Study of Insulin Glargine. Insulin glargine $(0.1 \mathrm{mM})$ dissolved in phosphate buffer $(\mathrm{pH} \mathrm{9.5,I=0.2)}$ in the absence and presence of the selected anionic $\beta$-CyDs $(10 \mathrm{mM})$ was precipitated by a $\mathrm{pH}$ shift to 7.4. After centrifugation $(2,500 \mathrm{rpm}, 10 \mathrm{~min})$, the supernatant was discarded, and then phosphate buffer ( $\mathrm{pH} 7.4, I=0.2)$ was newly added to the precipitate at $25^{\circ} \mathrm{C}$. At appropriate intervals, an aliquot of the dissolution medium was withdrawn, centrifuged at 2,500 rpm for $10 \mathrm{~min}$, and analyzed for the insulin glargine by HPLC as described above.

2.7. Stability of Insulin Glargine against Tryptic Cleavage. Insulin glargine $(0.1 \mathrm{mM})$ in phosphate buffer $(\mathrm{pH} 9.5, I=$ $0.2)$ was incubated with recombinant trypsin $(0.02 \mathrm{mg} / \mathrm{mL})$ in the absence and presence of the selected anionic $\beta$-CyDs at $37^{\circ} \mathrm{C}$. At appropriate intervals, $5 \mu \mathrm{L}$ of sample solution was withdrawn and determined intact insulin glargine level by HPLC. The rate constants $\left(k_{c}\right)$ and stability constants $\left(K_{c}\right)$ of $1: 1$ complexes of insulin glargine/ $\beta$-CyDs under the tryptic cleavage were determined by a quantitative analysis according to the following equation, where $k_{0}$ and $[C y D]_{t}$ stand for the rate constants without $\mathrm{CyD}$ and the total concentration of CyD, respectively [21]:

$$
\frac{[C y D]_{t}}{k_{0}-k_{\mathrm{obs}}}=\frac{1}{k_{0}-k_{c}} \cdot[C y D]_{t}+\frac{1}{K_{c} \cdot\left(k_{0}-k_{c}\right)} .
$$

2.8. Pharmacokinetics and Pharmacodynamics of Insulin Glargine. The solution $(0.582 \mathrm{~mL} / \mathrm{kg})$ containing insulin glargine $(2 \mathrm{IU} / \mathrm{kg})$ in phosphate buffer $(\mathrm{pH} 9.5, I=0.2)$ in the absence and presence of the selected anionic of $\beta$-CyDs was subcutaneously injected in male Wistar rats (200-250 g), and, at appropriate intervals, blood samples were taken from the jugular veins. Serum insulin glargine and glucose were determined by Glyzyme Insulin-EIA Test Wako (Wako Pure Chemicals, Osaka, Japan) and Glucose-CII-Test Wako (Wako Pure Chemicals Ind., Osaka, Japan), respectively. Serum glucose levels after the administration of a solution of insulin glargine with or without the selected anionic $\beta$-CyDs were expressed as a percentage of the initial glucose level before injection.
2.9. Statistical Analysis. Data are given as the mean \pm S.E.M. Statistical significance of means for the studies was determined by analysis of variance followed by Scheffe's test. $P$-values for significance were set at 0.05 .

\section{Results and Discussion}

3.1. Spectroscopic Studies. CyDs have been claimed to interact with hydrophobic residues exposed on protein surfaces and thereby to decrease the aggregation of proteins [22, $23]$. We previously reported that SBE4- $\beta$-CyD inhibited the aggregation of bovine insulin in neutral solution, possibly due to the interaction of SBE4- $\beta$-CyD with aromatic side chain of insulin such as B26-tyrosine, A19-tyrosine, B1phenylalanine, and B25-phenylalanine [17]. Also, our recent study has shown that SBE4- $\beta$-CyD increased solubility of insulin glargine, enhanced the dissolution rate from its precipitate, and inhibited its aggregation in phosphate buffer ( $\mathrm{pH} 9.5, I=0.2$ ), with all possibly due to the formation of complex with insulin glargine [19]. In the present study, to reveal whether the selected anionic CyD derivatives, Sul- $\beta$ CyD, and SBE7- $\beta-C y D$, interact with insulin glargine, the effects of both of the selected anionic $\beta$-CyDs $(10 \mathrm{mM})$ on the fluorescence and $\mathrm{CD}$ spectra of insulin glargine were investigated $(0.1 \mathrm{mM})$ (Figure 2$)$. To obtain the clear solution of insulin glargine $(0.1 \mathrm{mM})$ in spectroscopic studies, insulin glargine with the selected anionic $\beta$-CyDs was dissolved in phosphate buffer $(\mathrm{pH} 9.5, I=0.2)$ at $25^{\circ} \mathrm{C}$. The fluorescence intensity of tyrosine of insulin glargine at $306 \mathrm{~nm}$ was remarkably quenched by the addition of Sul- $\beta$-CyD $(10 \mathrm{mM})$ while SBE7- $\beta$-CyD $(10 \mathrm{mM})$ quenched slightly (Figure 2(a)). As tyrosine is a hydrophobic amino acid having a phenyl group in the molecule, these selected anionic $\beta$-CyDs may interact with those aromatic amino acid residues of insulin glargine. The apparent 1:1 stability constants $\left(K_{c}\right)$ of the insulin glargine/Sul- $\beta$-CyD complex and insulin glargine/SBE7- $\beta$-CyD complex were determined by the titration curves of the fluorescence intensity against the concentration of the selected anionic $\beta-\mathrm{CyD}$ with the Scott's equation [21]. The $K_{c}$ values of insulin glargine/Sul- $\beta$ $\mathrm{CyD}$ complex and insulin glargine/SBE7- $\beta$-CyD complex in phosphate buffer $(\mathrm{pH} 9.5, I=0.2)$ at $25^{\circ} \mathrm{C}$ were calculated to be $14 \pm 3 \mathrm{M}^{-1}$ and $18 \pm 4 \mathrm{M}^{-1}$, respectively. The CD spectrum of insulin glargine $(0.1 \mathrm{mM})$ showed negative bands at $210 \mathrm{~nm}$ and $220 \mathrm{~nm}$ in phosphate buffer ( $\mathrm{pH} 9.5$, $I=0.2$ ) (Figure 2(b)). The two negative bands assigned to $\alpha$-helics (a characteristic feature of the monomer) and $\beta$ sheets (a predominant feature of dimer) structures [24]. In the presence of Sul- $\beta$-CyD $(10 \mathrm{mM})$, the both negative bands at $210 \mathrm{~nm}$ and $220 \mathrm{~nm}$ in the CD spectrum of insulin glargine remarkably increased. These results indicate that Sul- $\beta$-CyD decreased the content of monomer and dimer of insulin glargine in phosphate buffer $(\mathrm{pH} 9.5, I=0.2)$. Meanwhile, the $\mathrm{CD}$ spectrum of insulin glargine in the presence of SBE7- $\beta$-CyD was changed only very slightly, compared to that of insulin glargine alone, suggesting that SBE7- $\beta$-CyD did not induce a conformational change of insulin glargine in phosphate buffer $(\mathrm{pH} 9.5, I=0.2)$. To gain insight into the mechanism of the interaction mode of these 


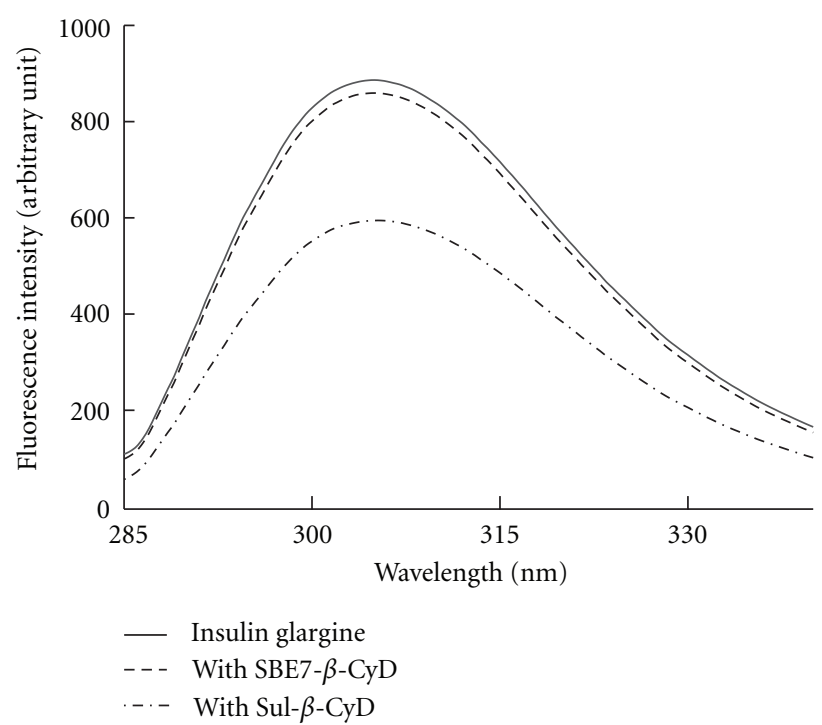

(a)

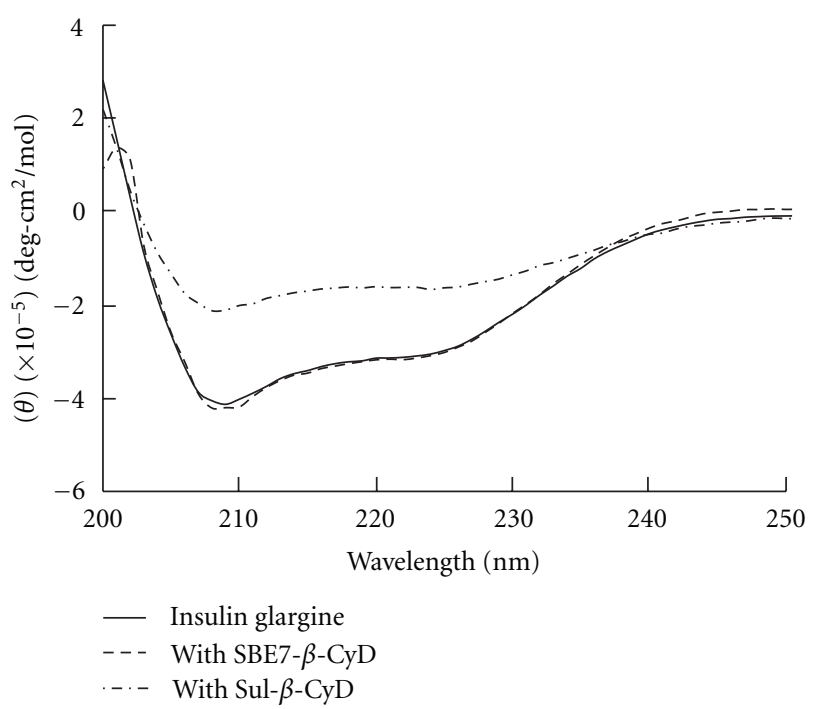

(b)

FIGURE 2: Effects of Sul- $\beta$-CyD and SBE7- $\beta$-CyD $(10 \mathrm{mM})$ on fluorescence spectrum (a), circular dichroism spectrum of insulin glargine

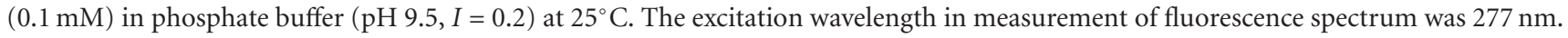

anionic $\beta$-CyDs with insulin glargine, further investigation should be required using NMR technique. Collectively, these results strongly suggest that the interaction mode of Sul$\beta$-CyD and SBE7- $\beta$-CyD against insulin glargine is much different; namely, Sul- $\beta$-CyD, but not SBE7- $\beta$-CyD, induces topological change of insulin glargine in phosphate buffer $(\mathrm{pH} 9.5, I=0.2)$, and this difference may contribute to explaining the observed differences in in vivo behavior as well.

3.2. Solubility Studies. The preferred presentation for administration by subcutaneous injection is a clear aqueous solution, and so this is the desired form for administration of insulin and its analogues. However, insulin or insulin analogues are poorly soluble in aqueous solution, in particular at around their isoelectric point (pI), approximately $\mathrm{pH}$ 6.7, close to the physiological pH [25]. Hence, the effects of Sul- $\beta$ CyD and SBE7- $\beta-$ CyD on solubility of insulin glargine were examined. As shown in Figure 3, the solubility of insulin glargine in phosphate buffer at $\mathrm{pH} 9.5$ was significantly increased by the addition of Sul- $\beta-\mathrm{CyD}$ or SBE7- $\beta-\mathrm{CyD}$ and so appears to be due to an inclusion complexation and electrostatic interaction between insulin glargine and the selected anionic $\beta$-CyDs. These results suggest that Sul- $\beta$ CyD and SBE7- $\beta$-CyD potentially enhance the solubility of insulin glargine in phosphate buffer.

3.3. Ultrafiltration Studies. The aggregation and selfassociation of insulin and its analogue are elicited by many kinds of factors such as the concentration of insulin, $\mathrm{pH}$, temperature, shaking, and so on $[5,6]$. Insulin glargine forms dimer, tetramer, hexamer, and further soluble oligomers by

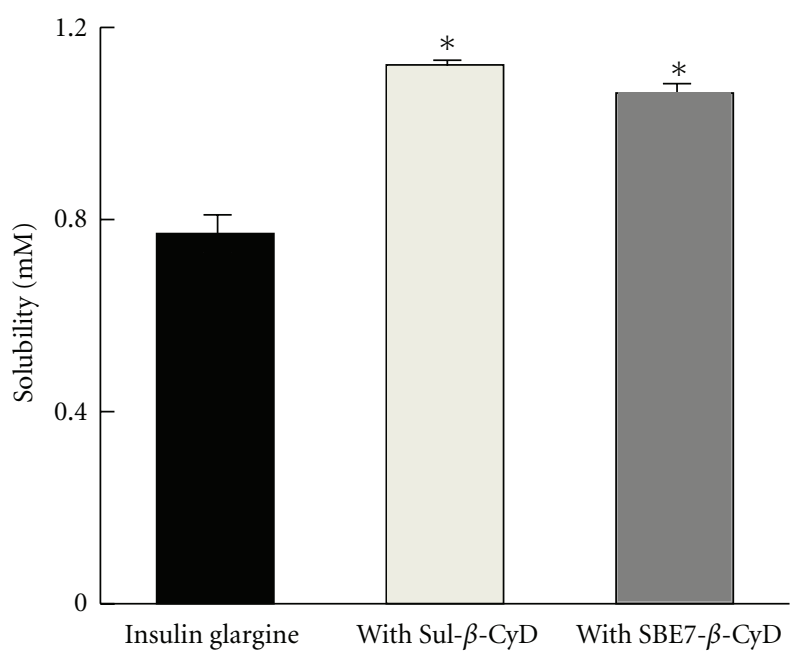

Figure 3: Effects of Sul- $\beta$-CyD and SBE7- $\beta$-CyD ( $10 \mathrm{mM})$ on solubility of insulin glargine in phosphate buffer $(\mathrm{pH} 9.5, I=0.2)$ at $25^{\circ} \mathrm{C}$. Each value represents the mean \pm S.E.M. of 3 experiments. ${ }^{*} P<0.05$, compared to insulin glargine.

noncovalent interactions such as proceeding from selfassociation $[26,27]$. Therefore, we performed ultrafiltration studies to estimate the effects of Sul- $\beta-$ CyD and SBE7- $\beta-C y D$ on self-association of insulin glargine using the membrane YM30 $(\mathrm{MWCO}=30,000)$ in phosphate buffer $(\mathrm{pH} 9.5, I=$ 0.2 ). As shown in Figure 4, insulin glargine in the absence of $\beta$-CyDs permeated the ultrafiltration membrane by approximately $50 \%$. SBE7- $\beta$-CyD significantly enhanced the permeation of insulin glargine up to almost $70 \%$. These 


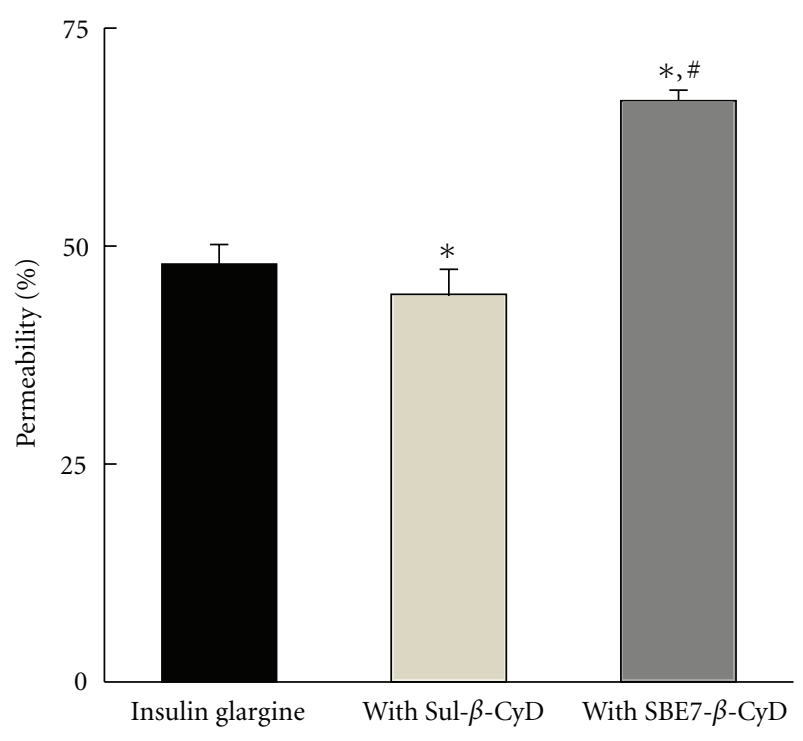

Figure 4: Effects of Sul- $\beta$-CyD and SBE7- $\beta$-CyD $(10 \mathrm{mM})$ on permeation of insulin glargine $(0.1 \mathrm{mM})$ through ultrafiltration membrane having nominal molecular weight limit of 30,000 in phos-

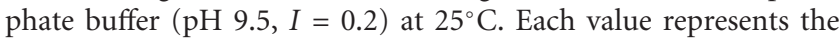
mean \pm S.E.M. of 17 and 5 experiments for insulin glargine and with Sul- $\beta$-CyD or SBE7- $\beta$-CyD, respectively. ${ }^{*} P<0.05$, compared to insulin glargine. ${ }^{\#} P<0.05$, compared to Sul- $\beta-\mathrm{CyD}$.

results suggest that interaction with SBE7- $\beta$-CyD results in dissociation of such soluble oligomers of insulin glargine. On the other hand, the presence of Sul- $\beta$-CyD slightly, but significantly decreased the permeation of insulin glargine to approximately $45 \%$, although not accompanied by observable formation of insoluble aggregates of insulin glargine under the prevailing experimental condition. Recall from above, that Sul- $\beta$-CyD decreased the contents of monomer and dimer of insulin glargine in phosphate buffer $(\mathrm{pH} 9.5, I=0.2)$ (Figure 2(b)). Therefore, these results, taken together, indicate that Sul- $\beta-\mathrm{CyD}$ enhanced the association of soluble oligomer of insulin glargine from its monomer and dimer.

3.4. Particle Size Determination. The apparent particle sizes of insulin glargine were determined by the dynamic light scattering method in the absence and presence of Sul- $\beta$-CyD and SBE7- $\beta$-CyD (Table 1). Particle size of insulin glargine alone in phosphate buffer ( $\mathrm{pH} 9.5, I=0.2)$ was determined as $744 \pm 82 \mathrm{~nm}$. Particle sizes of insulin glargine in the presence of Sul- $\beta-$ CyD and SBE7- $\beta-C y D$ increased significantly to $1334 \pm 164 \mathrm{~nm}$ and $1575 \pm 228 \mathrm{~nm}$, respectively. It is estimated that the sulfate and sulfobutyl groups of Sul- $\beta$ $\mathrm{CyD}$ and SBE7- $\beta$-CyD are both strongly hydrated in aqueous solution. Therefore, these results suggest that Sul- $\beta-\mathrm{CyD}$ and SBE7- $\beta$-CyD enhanced the particle size of insulin glargine in phosphate buffer.

3.5. Dissolution Study of Insulin Glargine. Insulin glargine is believed to precipitate at the physiological $\mathrm{pH}$ after
TABLE 1: Particle size of insulin glargine with or without Sul- $\beta$-CyD and SBE7- $\beta$-CyD $(10 \mathrm{mM})$ in phosphate buffer ( $\mathrm{pH} 9.5)$. The particle size was measured by a Zetasizer Nano. The concentrations of insulin glargine and $\beta$-CyDs were $0.1 \mathrm{mM}$ and $10 \mathrm{mM}$, respectively. Each value represents the mean \pm S.E.M. of 5-7 experiments.

\begin{tabular}{lc}
\hline System & Diameter $(\mathrm{nm})$ \\
\hline Insulin glargine & $744 \pm 82$ \\
With Sul- $\beta$-CyD & $1334 \pm 164^{*}$ \\
With SBE7- $\beta$-CyD & $1575 \pm 228^{*}$ \\
\hline
\end{tabular}

Uehata et al. [19]

subcutaneous injection of the solution due to pI (about $\mathrm{pH}$ 6.7), which is followed by a sustained release of insulin glargine over $24 \mathrm{~h}$ at an injection site because of its extremely low solubility in aqueous solution at $\mathrm{pH}$ of around $\mathrm{pI}$ [6]. In order to investigate the effects of Sul- $\beta-\mathrm{CyD}$ and SBE7$\beta-\mathrm{CyD}$ on the sustained release of insulin glargine, the dissolution rate of insulin glargine from isoelectric precipitates formed with or without $\beta$-CyDs was determined (Figure 5). Insulin glargine $(0.1 \mathrm{mM})$ was dissolved in phosphate buffer $(\mathrm{pH} 9.5)$ in the presence and absence of $\beta$-CyDs $(10 \mathrm{mM})$, and then isoelectric precipitation of insulin glargine was obtained after $\mathrm{pH}$ shift from 9.5 to 7.4. Then, the release rate of insulin glargine was determined in phosphate buffer $(\mathrm{pH}$ 7.4) in the absence of selected anionic $\beta$-CyDs. SBE7$\beta$-CyD significantly increased the dissolution rate of insulin glargine after $24 \mathrm{~h}$, compared to insulin glargine alone. This enhancing effect of SBE7- $\beta-C y D$ on the dissolution rate is consistent with its solubilizing effect as shown in Figure 3. On the other hand, Sul- $\beta-C y D$ appeared to decrease the dissolution rate of insulin glargine after $24 \mathrm{~h}$; however, no statistical significance was found. The inhibitory effect of Sul- $\beta-C y D$ on the dissolution rate of insulin glargine from its precipitate may be ascribed to the enhancement of the association of insulin glargine molecules that is dominant over the solubilizing effect of Sul- $\beta$-CyD on insulin glargine. To reiterate, SBE7- $\beta$-CyD, and not Sul- $\beta-C y D$, increases dissolution of insulin glargine from its precipitate.

3.6. Stability of Insulin Glargine against Tryptic Cleavage. Insulin and its analogues are digested by proteases such as trypsin, which cleaves insulin at the carboxyl side of residues B22-arginine and B29-lysine, at an injection site and systemic circulation [28]. Therefore, a resistance towards enzymatic degradation is required for a formulation of insulin or its analogues to demonstrate improvement in bioavailability. Next, the effects of Sul- $\beta$-CyD and SBE7- $\beta$-CyD on stability of insulin glargine against trypsin digestion were investigated. In this study, insulin glargine was digested by trypsin at $2 \mathrm{IU}$ at $\mathrm{pH} 9.5$ at $37^{\circ} \mathrm{C}$ with different degradation rates in the absence and presence of $\beta$-CyDs. As shown in Figure 6(a), the apparent degradation rate constant of insulin glargine alone $\left(k_{0}\right)$ was $0.357 \pm 0.004 \mathrm{~h}^{-1}$. Meanwhile, the apparent rate constants $\left(k_{\text {obs }}\right)$ in the presence of Sul- $\beta$-CyD and SBE7$\beta$-CyD decreased with the increase in the concentration of these $\beta$-CyDs. The decline in the $k_{\mathrm{obs}}$ value in the SBE7- $\beta$ CyD system was more than that in the Sul- $\beta-C y D$ system. 


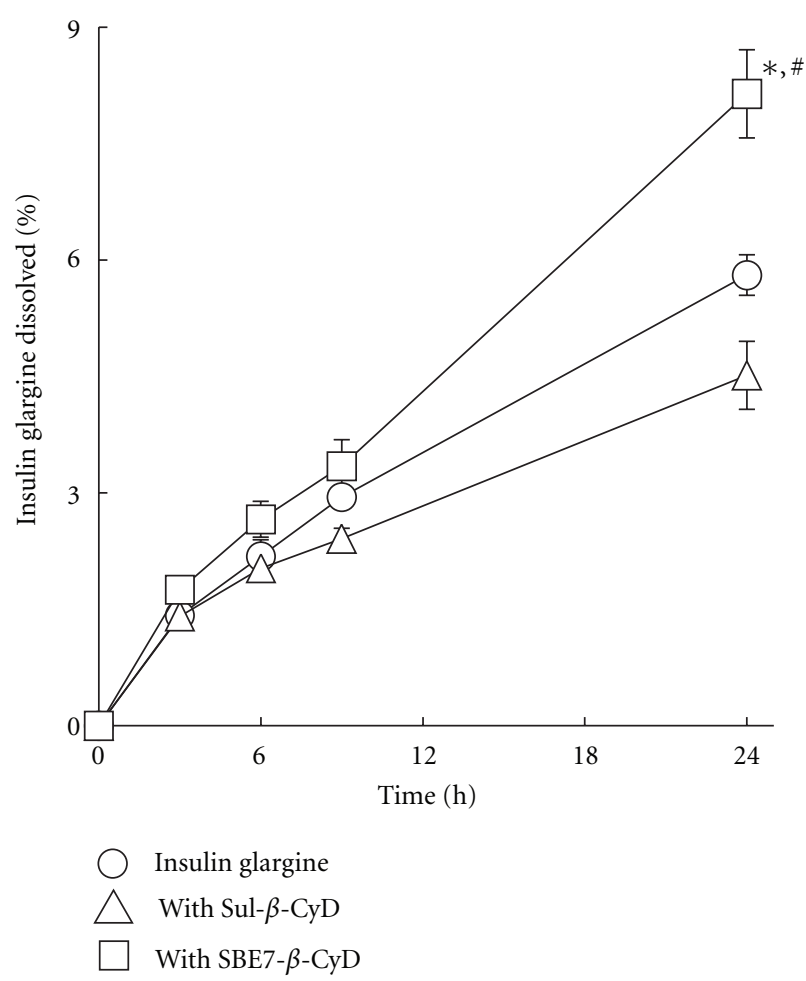

Figure 5: Effects of Sul- $\beta$-CyD and SBE7- $\beta$-CyD ( $10 \mathrm{mM})$ on dissolution from isoelectric precipitation of insulin glargine in phosphate buffer ( $\mathrm{pH} 9.5, I=0.2)$ at $25^{\circ} \mathrm{C}$. The initial concentration of insulin glargine was $0.1 \mathrm{mM}$ and then precipitated in phosphate buffer $(\mathrm{pH}$ 7.4). Each point represents the mean \pm S.E.M. of 3 experiments. ${ }^{*} P<0.05$, compared to insulin glargine. ${ }^{\#} P<0.05$, compared to Sul- $\beta$-CyD.

The rate constants $\left(k_{c}\right)$ and stability constants $\left(K_{c}\right)$ of the $1: 1$ complex calculated with the regression lines shown in the Figure $6(\mathrm{~b})$ were $0.129 \pm 0.009 \mathrm{~h}^{-1}$ and $244 \pm 24 \mathrm{M}^{-1}$ in the Sul- $\beta-$ CyD system and $0.137 \pm 0.014 \mathrm{~h}^{-1}$ and $182 \pm$ $22 \mathrm{M}^{-1}$ in the SBE7- $\beta$-CyD system, respectively. These results suggest that the inhibition of tryptic cleavage of insulin glargine by Sul- $\beta-\mathrm{CyD}$ and SBE7- $\beta-\mathrm{CyD}$ may be ascribed to the formation of the soluble oligomer and soluble complex with insulin glargine (Figures 3 and 4), respectively, resulting from decreasing the extent of the free insulin glargine that could be easily digested by trypsin. Our previous studies revealed that the $k_{c}$ and $K_{c}$ values in the SBE4- $\beta$-CyD system were $0.145 \pm 0.012 \mathrm{~h}^{-1}$ and $144 \pm 18 \mathrm{M}^{-1}$, respectively [19]. Therefore, it is evident that the inhibitory effect of SBE7- $\beta$ $\mathrm{CyD}$ on enzymatic degradation of insulin glargine is more potent than that of SBE4- $\beta$-CyD.

Recently, it has been reported that the aspartic acid residue existing in the catalytic pocket of trypsin is responsible for attracting and stabilizing positively charged lysine and/or arginine on the substrate peptide [29]. Therefore, the insulin glargine/Sul- $\beta-\mathrm{CyD}$ interaction or insulin glargine/SBE7- $\beta$-CyD complex is speculated to ameliorate the interaction between the negatively charged aspartic acid in the catalytic pocket of trypsin and positively charged lysine and/or arginines mentioned earlier, since Sul- $\beta-\mathrm{CyD}$ and SBE7- $\beta$-CyD have negative charge originating from the sulfate and sulfonate groups, respectively. This hypothesis in which the insulin glargine/Sul- $\beta$-CyD interaction and insulin glargine/SBE7- $\beta$-CyD complex ameliorate the interaction between the aspartic acid and lysine and/or arginines is supported by the finding that the aromatic amino acid residues in insulin glargine which are capable of interacting with $\beta$-CyDs (at B24-, B25-phenylalanines, B26-tyrosine, and $\mathrm{B} 28$-proline) locate near the three digestive sites by trypsin (B22-B23, B29-B30, and B31-B32) [17]. These results suggest that Sul- $\beta-\mathrm{CyD}$ and $\mathrm{SBE} 7-\beta-\mathrm{CyD}$ act as stabilizers of insulin glargine against enzymatic degradation by their respective interactions with insulin glargine.

3.7. Subcutaneous Administration of Insulin Glargine/ $\beta-C y D s$ Solutions to Rats. To confirm whether Sul- $\beta$-CyD and SBE7$\beta-\mathrm{CyD}$ are useful excipients for insulin glargine in vivo, we evaluated the effects of the $\beta$-CyDs on pharmacokinetics and pharmacodynamics of insulin glargine after subcutaneous injection to rats. In our preliminary studies, we found that neither Sul- $\beta$-CyD $(100 \mathrm{mM})$ nor SBE7- $\beta$-CyD $(100 \mathrm{mM})$ changed the serum glucose level-time profiles remarkably in comparison with that of insulin glargine alone $(2 \mathrm{IU} / \mathrm{kg}$ ) after subcutaneous injection to rats (data not shown). Taking the positive results of SBE7- $\beta-C y D$ in ultrafiltration (Figure 2) and dissolution (Figure 3) studies by contrast to those of Sul- $\beta$-CyD into account, further in vivo investigation was performed with a higher concentration of SBE7- $\beta$-CyD. Figure 7(a) and Table 2 show the serum insulin glargine level-time profiles and pharmacokinetics parameters, respectively, after subcutaneous administration of insulin glargine $(2 \mathrm{IU} / \mathrm{kg})$ with or without SBE7- $\beta-\mathrm{CyD}$ $(200 \mathrm{mM})$ in phosphate buffer $(\mathrm{pH} 9.5)$ to rats. When insulin glargine alone was injected, the maximum level $\left(C_{\max }\right)$ of insulin glargine and the time $\left(T_{\max }\right)$ required to the reach $C_{\max }$ after injection were $150 \mu \mathrm{U} / \mathrm{mL}$ and $1.00 \mathrm{~h}$, respectively. In the presence of SBE7- $\beta$-CyD $(200 \mathrm{mM}), C_{\max }$ significantly decreased to $91.60 \mu \mathrm{U} / \mathrm{mL}$ although $T_{\max }$ did not change remarkably, compared to that of insulin glargine alone. The area under the serum insulin glargine level-time curve (AUC) in the SBE7- $\beta$-CyD system $(200 \mathrm{mM})$ up to $12 \mathrm{~h}$ $(687.86(\mu \mathrm{U} / \mathrm{mL}) \cdot \mathrm{h})$ was significantly increased, compared to those of insulin glargine alone $(582.99(\mu \mathrm{U} / \mathrm{mL}) \cdot \mathrm{h})$. In addition, SBE7- $\beta$-CyD $(200 \mathrm{mM})$ extended the mean residence time (MRT) of the serum insulin glargine level significantly, comparing with that of insulin glargine alone. These results indicate that SBE7- $\beta$-CyD sustained the serum insulin glargine level.

Figure 7(b) and Table 3 show the serum glucose leveltime profiles and pharmacodynamics parameters after subcutaneous administration of insulin glargine $(2 \mathrm{IU} / \mathrm{kg}$ ) with or without SBE7- $\beta$-CyD $(200 \mathrm{mM})$ in the phosphate buffer $(\mathrm{pH} 9.5)$ to rats. When insulin glargine alone was administered, the time to nadir blood glucose concentration ( $\left.T_{\text {nadir }}\right)$ was $1.6 \mathrm{~h}$ after injection, and then the blood glucose levels recovered within $6 \mathrm{~h}$ to basal level. On the other hand, insulin glargine administered with SBE7- $\beta$-CyD significantly retained the blood-glucose lowering effect up 


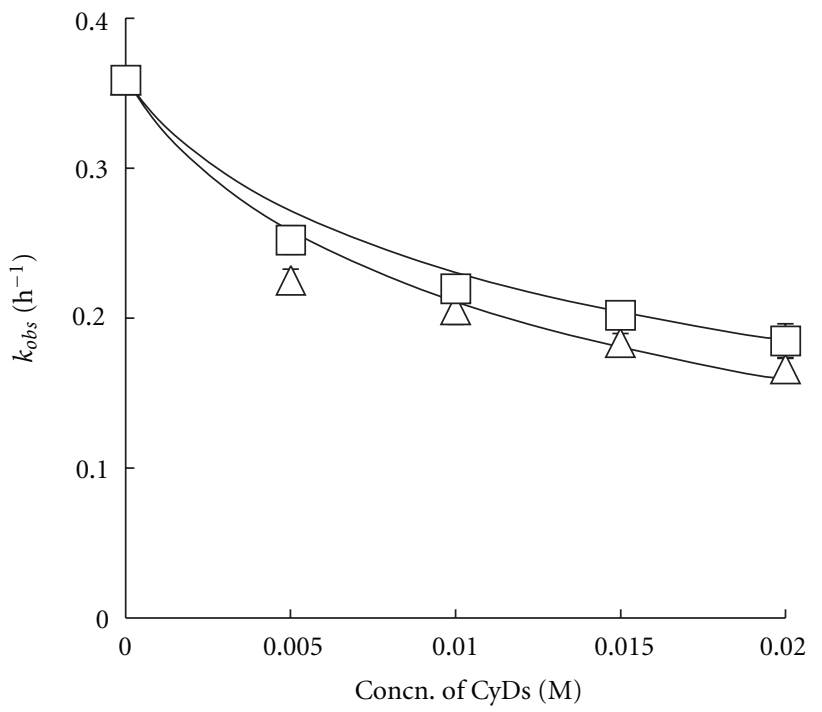

$\triangle \quad$ With Sul- $\beta-C y D$
$\square \quad$ With SBE7- $\beta-C y D$

(a)

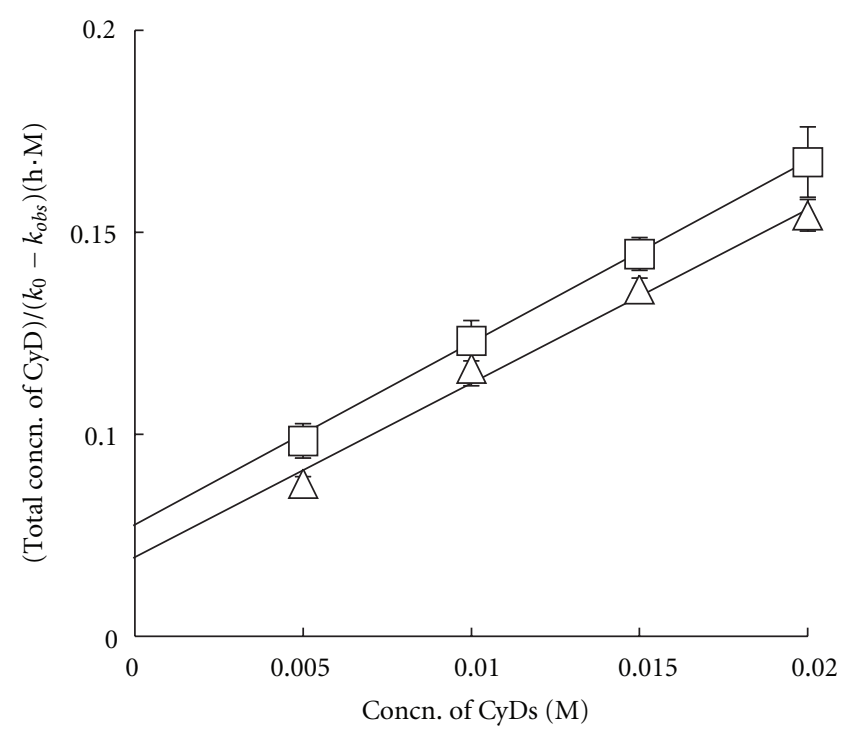

$\triangle$ With Sul- $\beta$-CyD

With SBE7- $\beta-\mathrm{CyD}$

(b)

FIGURE 6: Effects of Sul- $\beta$-CyD and SBE7- $\beta$-CyD ( 5 to $20 \mathrm{mM}$ ) on tryptic cleavage ( $2 \mathrm{IU})$ of insulin glargine $(0.1 \mathrm{mM})$ in phosphate buffer $(\mathrm{pH} 9.5, I=0.2)$ at $37^{\circ} \mathrm{C}$. Each point represents the mean \pm S.E.M. of 3 experiments.

TABLE 2: In vivo pharmacokinetics parameters of insulin glargine with or without SBE7- $\beta$-CyD (200 mM). (1) Time required to reach the maximum serum insulin glargine level. (2) Maximum serum insulin glargine level. (3) Area under the serum insulin glargine level-time curve up to $12 \mathrm{~h}$ after-administration. (4) Mean residence time in plasma. Each value represents the mean \pm S.E.M. of 4-6 experiments. ${ }^{*} P<0.05$, compared to insulin glargine.

\begin{tabular}{|c|c|c|c|c|}
\hline System & $\mathrm{T}_{\max }^{(1)}(\mathrm{h})$ & $\mathrm{C}_{\max }^{(2)}(\mu \mathrm{U} / \mathrm{mL})$ & $\begin{array}{c}\mathrm{AUC}^{(3)} \\
((\mathrm{mU} / \mathrm{mL}) \mathrm{h})\end{array}$ & $\mathrm{MRT}^{(4)}(\mathrm{h})$ \\
\hline Insulin glargine & $1.00 \pm 0.00$ & $150.00 \pm 17.90$ & $582.99 \pm 30.27$ & $1.83 \pm 0.08$ \\
\hline $\begin{array}{l}\text { Insulin } \\
\text { glargine/SBE7- } \beta-\mathrm{CyD}\end{array}$ & $1.40 \pm 0.24$ & $91.60 \pm 3.04^{*}$ & $687.86 \pm 20.57^{*}$ & $2.12 \pm 0.04^{*}$ \\
\hline
\end{tabular}

to $6 \mathrm{~h}$ after administration. $T_{\text {nadir }}$ was significantly increased in the insulin glargine/SBE7- $\beta-\mathrm{CyD}$ system. Further, the insulin glargine/SBE7- $\beta$-CyD system showed the tendency to augment the area under serum glucose level-time curve $\left(\mathrm{AUC}_{\mathrm{G}}\right)$. The retained blood-glucose lowering effects and enhancement of $T_{\text {nadir }}$ by the addition of SBE7- $\beta$-CyD may be contributed to (1) the inhibitory effects of SBE7- $\beta-C y D$ on the enzymatic degradation of insulin glargine (Figure 6) and (2) the enhancement of solubility and the dissolution rate of insulin glargine by SBE7- $\beta$-CyD (Figures 3-5). However, the enhancement of bioavailability and persistence of the bloodglucose lowering effect of insulin glargine after subcutaneous injection to rats by SBE7- $\beta-\mathrm{CyD}$ was not superior to that of $\mathrm{SBE} 4-\beta-\mathrm{CyD}$. The reason for this may be due to the difference in adsorption of insulin glargine onto the subcutaneous tissue at injection site between the SBE7- $\beta$-CyD and SBE4- $\beta$-CyD systems [19]. To gain insight into the detailed mechanism, further study on the adsorption of insulin glargine in the presence of SBE- $\beta$-CyDs onto subcutaneous tissue at injection site is underway. These results suggest that SBE7- $\beta$-CyD increased the bioavailability and persistence of the blood-glucose lowering effect of insulin glargine after subcutaneous administration of an insulin glargine solution to rats.

\section{Conclusions}

In the present study, we revealed that Sul- $\beta$-CyD and SBE7$\beta$-CyD increased solubility of insulin glargine. Furthermore, SBE7- $\beta$-CyD suppressed the formation of oligomer and enhanced the dissolution rate of insulin glargine from its precipitate, compared to that of Sul- $\beta$-CyD. In addition, we demonstrated that SBE7- $\beta$-CyD increased the bioavailability and persistence of the blood-glucose lowering effect of insulin glargine after subcutaneous administration of an insulin glargine solution to rats, probably due to the inhibitory effects of SBE7- $\beta$-CyD on the enzymatic degradation at the injection site, resulting from the interaction 
TABLE 3: In vivo pharmacodynamics parameters of insulin glargine with or without SBE7- $\beta$-CyD (200 mM). (1) Time to nadir blood glucose concentration. (2) Nadir blood glucose concentration. (3) The cumulative percentage of change in serum glucose levels up to $12 \mathrm{~h}$ afteradministration. (4) Mean residence time in plasma. Each value represents the mean \pm S.E.M. of 5-6 experiments. ${ }^{*} P<0.05$, compared to insulin glargine.

\begin{tabular}{lcccc}
\hline System & $\mathrm{T}_{\text {nadir }}^{(1)}(\mathrm{h})$ & $\mathrm{C}_{\text {nadir }}^{(2)}(\%)$ & $\mathrm{AUC}_{\mathrm{G}}^{(3)}(\% \cdot \mathrm{h})$ & $\mathrm{MRT}(4)(\mathrm{h})$ \\
\hline Insulin glargine & $1.60 \pm 0.16$ & $33.14 \pm 1.10$ & $544.66 \pm 31.73$ & $2.28 \pm 0.03$ \\
$\begin{array}{l}\text { Insulin glargine/ } \\
\text { SBE7- } \beta \text {-CyD }\end{array}$ & $3.50 \pm 0.05^{*}$ & $32.05 \pm 4.73$ & $612.36 \pm 40.84$ & $2.29 \pm 0.01$ \\
\hline
\end{tabular}

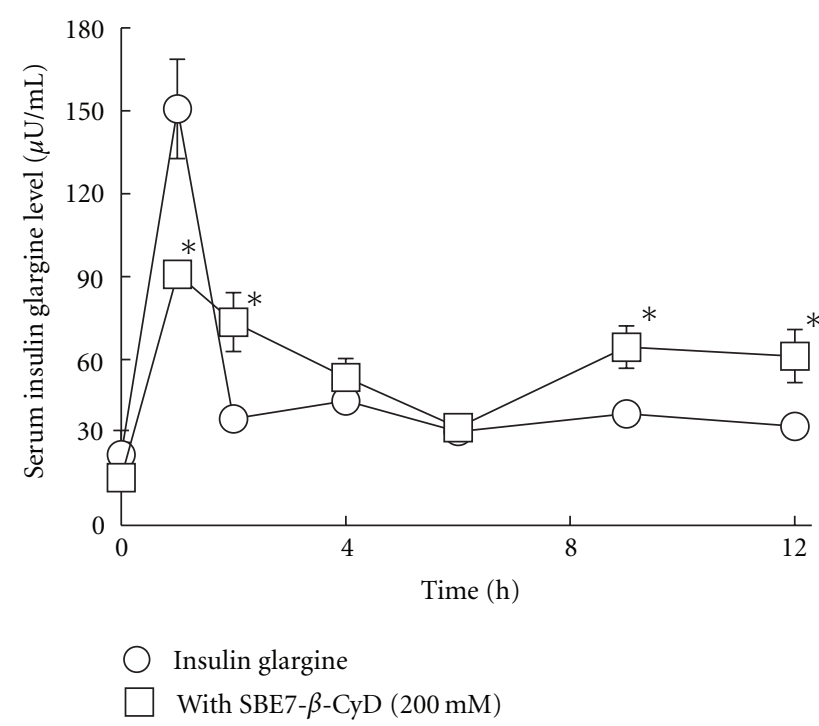

(a)

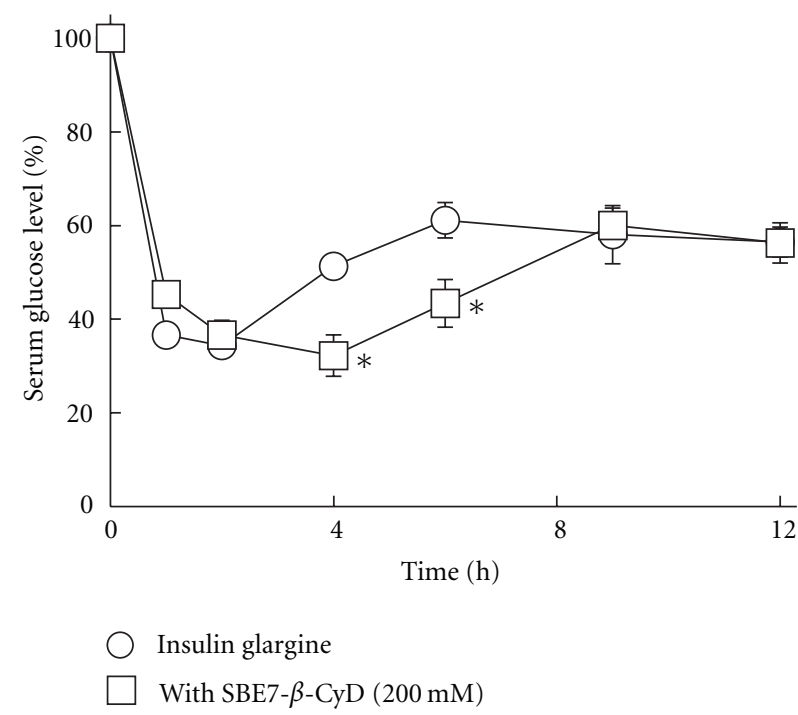

(b)

FIGURE 7: Effects of SBE7- $\beta$-CyD (200 mM) on serum insulin glargine (a) and glucose (b) levels after subcutaneous administration of insulin glargine $(2 \mathrm{IU} / \mathrm{kg})$ to rats. Each point represents the mean \pm S.E.M. of $4-6$ experiments. ${ }^{*} P<0.05$, compared to insulin glargine.

with insulin glargine molecules. These findings indicate that SBE7- $\beta$-CyD can be a useful excipient for a peakless profile of insulin glargine.

\section{Acknowledgments}

The work described in this paper presents additional results from a Joint Research Project by Kumamoto University and its collaboration partner CyDex Pharmaceuticals, Inc. and the authors wish to acknowledge this collaboration as well as funding support from CyDex Pharmaceuticals, Inc. The authors oblige to Sanofi-Aventis for the supply of insulin glargine.

\section{References}

[1] J. F. Blickle, J. Doucet, T. Krummel, and T. Hannedouche, "Diabetic nephropathy in the elderly," Diabetes and Metabolism, vol. 33, supplement 1, pp. S40-S55, 2007.

[2] B. Patterson, A. V. Fields, and R. P. Shannon, "New insights into myocardial glucose metabolism: surviving under stress," Current Opinion in Clinical Nutrition and Metabolic Care, vol. 12, no. 4, pp. 424-430, 2009.

[3] R. Simo, E. Carrasco, M. Garcia-Ramirez, and C. Hernandez, "Angiogenic and antiangiogenic factors in proliferative diabetic retinopathy," Current Diabetes Reviews, vol. 2, no. 1, pp. 71-98, 2006.

[4] E. S. Horton, "Can newer therapies delay the progression of type 2 diabetes mellitus?” Endocrine Practice, vol. 14, no. 5, pp. 625-638, 2008.

[5] A. Rolla, "Pharmacokinetic and pharmacodynamic advantages of insulin analogues and premixed insulin analogues over human insulins: impact on efficacy and safety," American Journal of Medicine, vol. 121, supplement 6, pp. S9-S19, 2008.

[6] F. Wang, J. M. Carabino, and C. M. Vergara, "Insulin glargine: a systematic review of a long-acting insulin analogue," Clinical Therapeutics, vol. 25, no. 6, pp. 1541-1577, 2003.

[7] L. Szente and J. Szejtli, "Highly soluble cyclodextrin derivatives: chemistry, properties, and trends in development," Advanced Drug Delivery Reviews, vol. 36, no. 1, pp. 17-28, 1999.

[8] K. Uekama, F. Hirayama, and T. Irie, "Cyclodextrin drug carrier systems," Chemical Reviews, vol. 98, no. 5, pp. 20452076, 1998.

[9] K. Shiotani, T. Irie, K. Uekama, and Y. Ishimaru, "Cyclodextrin sulfates in parenteral use: protection against gentamicin nephrotoxicity in the rat," European Journal of Pharmaceutical Sciences, vol. 3, no. 3, pp. 139-151, 1995.

[10] V. J. Stella and R. A. Rajewski, "Cyclodextrins: their future in drug formulation and delivery," Pharmaceutical Research, vol. 14, no. 5, pp. 556-567, 1997. 
[11] K. Uekama, "Design and evaluation of cyclodextrin-based drug formulation," Chemical and Pharmaceutical Bulletin, vol. 52, no. 8, pp. 900-915, 2004.

[12] K. Uekama and M. Otagiri, "Cyclodextrins in drug carrier systems," Critical Reviews in Therapeutic Drug Carrier Systems, vol. 3, no. 1, pp. 1-40, 1987.

[13] V. J. Stella and Q. He, "Cyclodextrins," Toxicologic Pathology, vol. 36, no. 1, pp. 30-42, 2008.

[14] T. Irie and K. Uekama, "Pharmaceutical applications of cyclodextrins. III. Toxicological issues and safety evaluation," Journal of Pharmaceutical Sciences, vol. 86, no. 2, pp. 147-162, 1997.

[15] K. Tokihiro, T. Irie, P. Hirayama, and K. Uekama, "Mass spectroscopic evidence on inhibiting effect of maltosyl- $\beta$ cyclodextrin on insulin self-association," Pharmaceutical Sciences, vol. 2, no. 11, pp. 519-522, 1996.

[16] K. Tokihiro, T. Irie, and K. Uekama, "Potential use of maltosyl$\beta$-cyclodextrin for inhibition of insulin self-association in aqueous solution," Journal of Pharmaceutical Sciences, vol. 1, pp. 49-53, 1995.

[17] K. Tokihiro, T. Irie, and K. Uekama, "Varying effects of cyclodextrin derivatives on aggregation and thermal behavior of insulin in aqueous solution," Chemical and Pharmaceutical Bulletin, vol. 45, no. 3, pp. 525-531, 1997.

[18] K. Tokihiro, H. Arima, S. Tajiri, T. Irie, T. Hirayama, and K. Uekama, "Improvement of subcutaneous bioavailability of insulin by sulphobutyl ether $\beta$-cyclodextrin in rats," Journal of Pharmacy and Pharmacology, vol. 52, no. 8, pp. 911-917, 2000.

[19] K. Uehata, T. Anno, K. Hayashida et al., "Effect of sulfobutyl ether- $\beta$-cyclodextrin on bioavailability of insulin glargine and blood glucose level after subcutaneous injection to rats," International Journal of Pharmaceutics. In press.

[20] J. Pitha, L. M. Mallis, D. J. Lamb, T. Irie, and K. Uekama, "Cyclodextrin sulfates: characterization as polydisperse and amorphous mixtures," Pharmaceutical Research, vol. 8, no. 9, pp. 1151-1154, 1991.

[21] K. Ikeda, K. Uekama, and M. Otagiri, "Inclusion complexes of $\beta$-cyclodextrin with antiinflammatory drugs fenamates in aqueous solution," Chemical and Pharmaceutical Bulletin, vol. 23, no. 1, pp. 201-208, 1975.

[22] M. E. Brewster, M. S. Hora, J. W. Simpkins, and N. Bodor, "Use of 2-hydroxypropyl- $\beta$-cyclodextrin as a solubilizing and stabilizing excipient for protein drugs," Pharmaceutical Research, vol. 8, no. 6, pp. 792-795, 1991.

[23] S. Tavornvipas, F. Hirayama, S. Takeda, H. Arima, and K. Uekama, "Effects of cyclodextrins on chemically and thermally induced unfolding and aggregation of lysozyme and basic fibroblast growth factor," Journal of Pharmaceutical Sciences, vol. 95, no. 12, pp. 2722-2729, 2006.

[24] J. Goldman and F. H. Carpenter, "Zinc binding, circular dichroism, and equilibrium sedimentation studies on insulin (bovine) and several of its derivatives," Biochemistry, vol. 13, no. 22, pp. 4566-4574, 1974.

[25] J. Brange, L. Andersen, E. D. Laursen, G. Meyn, and E. Rasmussen, "Toward understanding insulin fibrillation," Journal of Pharmaceutical Sciences, vol. 86, no. 5, pp. 517-525, 1997.

[26] S. Havelund, A. Plum, U. Ribel et al., "The mechanism of protraction of insulin detemir, a long-acting, acylated analog of human insulin," Pharmaceutical Research, vol. 21, no. 8, pp. 1498-1504, 2004.

[27] P. Kurtzhals, "Engineering predictability and protraction in a basal insulin analogue: the pharmacology of insulin detemir,"
International Journal of Obesity, vol. 28, supplement 2, pp. S23-S28, 2004.

[28] R. J. Schilling and A. K. Mitra, "Degradation of insulin by trypsin and $\alpha$-chymotrypsin," Pharmaceutical Research, vol. 8, no. 6, pp. 721-727, 1991.

[29] H. K. S. Leiros, B. O. Brandsdal, O. A. Andersen et al., "Trypsin specificity as elucidated by LIE calculations, X-ray structures, and association constant measurements," Protein Science, vol. 13, no. 4, pp. 1056-1070, 2004 

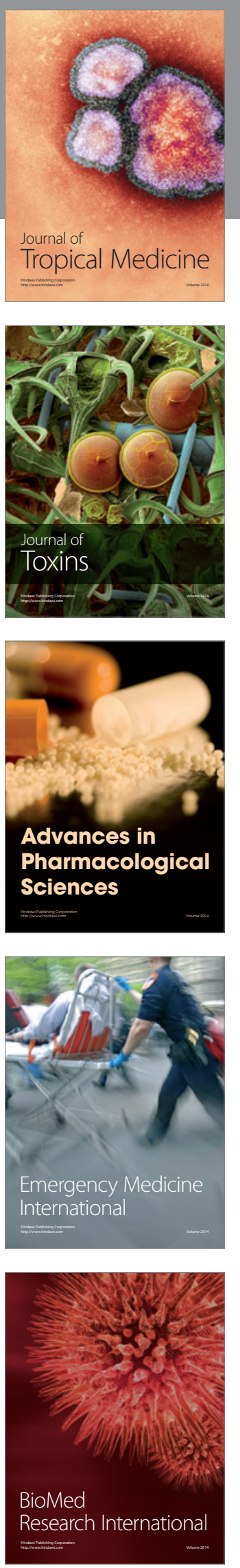
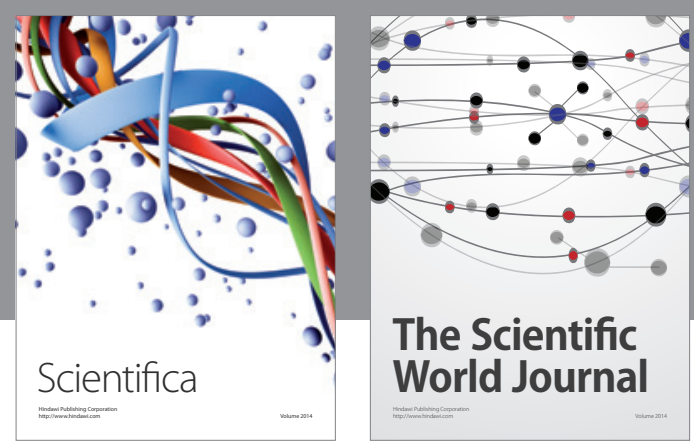

The Scientific World Journal
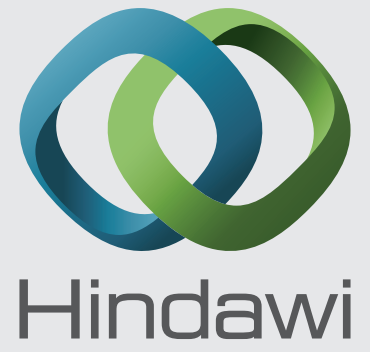

Submit your manuscripts at

http://www.hindawi.com
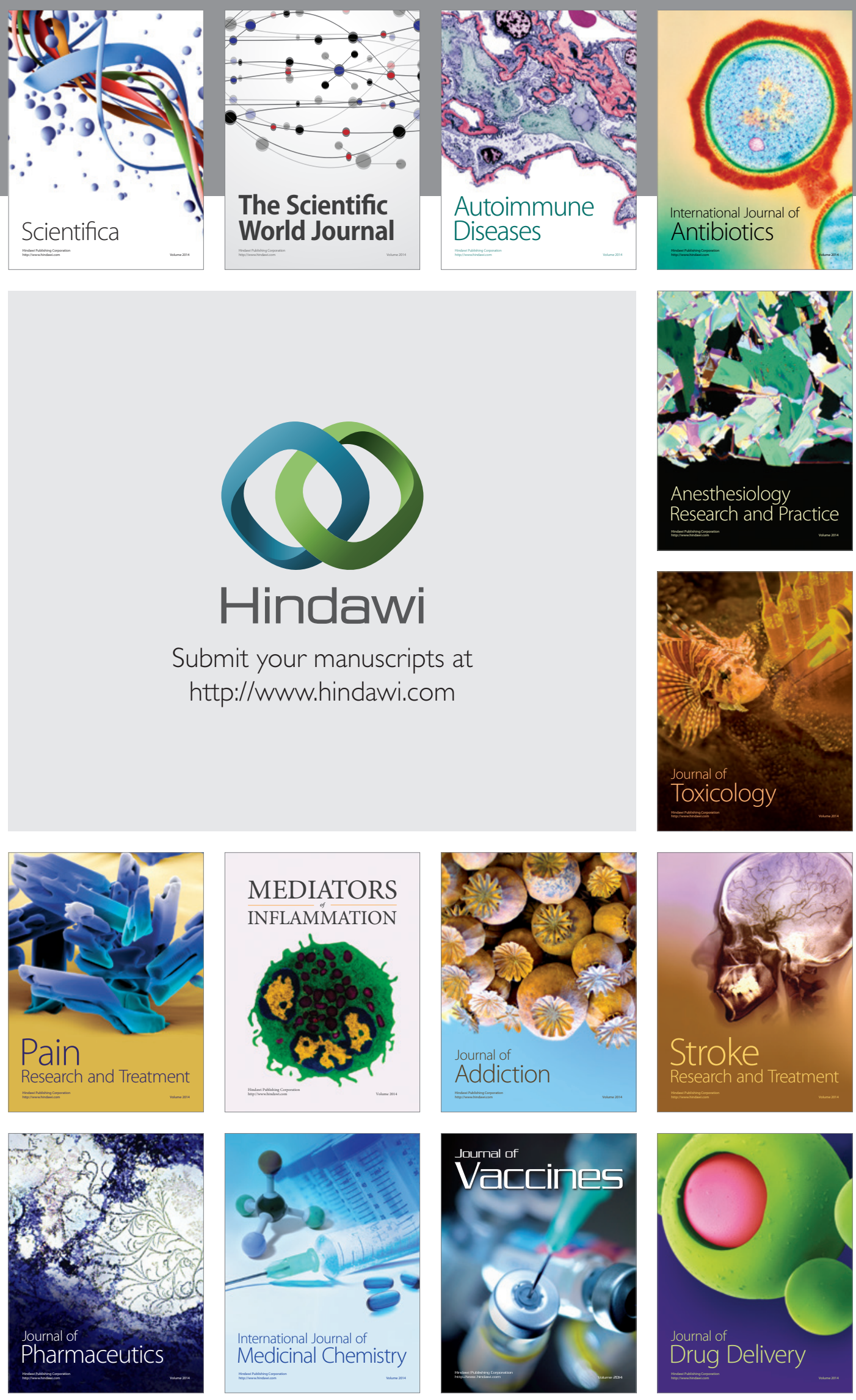